REFLECTIONS:

NEUROLOGY AND

THE HUMANITIES

Section Editor

Anne W. McCammon,

MD, FAAN

\title{
Modern Clinical Practice
}

Ramachandiran

Nandhagopal, MBBS,

$\mathrm{DM}$

Correspondence \& reprint

requests to Dr. Nandhagopal: rnandagopal@yahoo.com
A poem penned along the lines ${ }^{1}$ of the great poet, Alexander Pope, 1688-1744:

iPad from all clinicians glows the book of evidence,

All but the page subscribed, the practice guidance:

From conjurers what experts, from experts what trialists know;

Or who could face the dark below?

The man with a stroke arrives within the time window,

Without landmark trials, would he receive the lytic flow?

Thanks to the care, he regains his strength

And wears his smile by the third month.

$\mathrm{Oh}$, the levels of evidence! kindly described,

That each may provide the care prescribed:

Who guides the care beyond chance of all,

A pill succeed, or a placebo fall.

\section{REFERENCE}

1. Pope A. Essay on Man_Part 3. Available at: http://www.ardue.org.uk/garden/0608.html. Accessed January 20, 2012. 


\title{
Neurology
}

\author{
Modern Clinical Practice \\ Ramachandiran Nandhagopal \\ Neurology 2012;78;2003 \\ DOI 10.1212/WNL.0b013e318259e2f2
}

\section{This information is current as of June 11, 2012}

\section{Updated Information \& Services}

\section{Subspecialty Collections}

Permissions \& Licensing

\section{Reprints}

including high resolution figures, can be found at: http://n.neurology.org/content/78/24/2003.full

This article, along with others on similar topics, appears in the following collection(s):

\section{All Clinical trials}

http://n.neurology.org/cgi/collection/all_clinical_trials

All Practice Management

http://n.neurology.org/cgi/collection/all_practice_management

Information about reproducing this article in parts (figures,tables) or in its entirety can be found online at:

http://www.neurology.org/about/about_the_journal\#permissions

Information about ordering reprints can be found online:

http://n.neurology.org/subscribers/advertise

Neurology ${ }^{\circledR}$ is the official journal of the American Academy of Neurology. Published continuously since 1951, it is now a weekly with 48 issues per year. Copyright Copyright (? 2012 by AAN Enterprises, Inc.. All rights reserved. Print ISSN: 0028-3878. Online ISSN: 1526-632X.

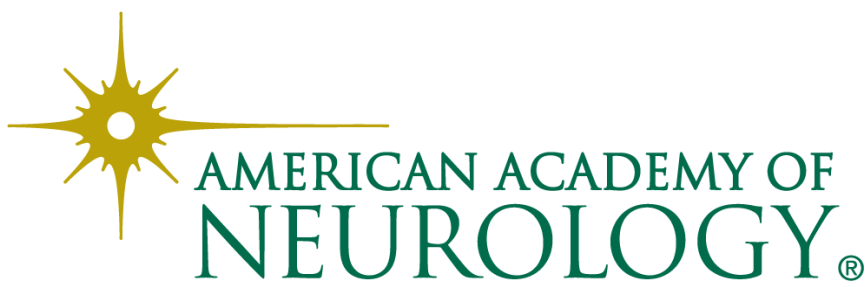

